\title{
Syysvehnän typpilannoituksen ajoittamisesta
}

\author{
Eero Varis ja Tapio JuUti \\ Hankkijan kasvinjalostuslaitos, Anttilan koetila, Hyrylä
}

\section{Timing of nitrogen application in winter wheat production}

EERo VARIS and TAPIO JUUTI

Hankkija Plant Breeding Institute, Experimental Farm Anttila, Hyrylä, Finland

\begin{abstract}
Absract. The following results were obtained in a study made from $1968-70$ at the Hankkija Plant Breeding Institute, the Experimental Farm, Anttila, to clarify the effects of nitrogen application and its timing upon the performance of winter wheat: 1. The most favourable time of application depended upon the size of the nitrogen dressing. The smallest quantity used, $50 \mathrm{~kg} \mathrm{~N} / \mathrm{ha}$, was best applied in spring, whereas the $100 \mathrm{~kg} \mathrm{~N} /$ ha application gave the best result when put on in the autumn. A 100 $\mathrm{kg}$ dressing of nitrogen applied in spring proved excessive in a single dose. Split into two applications it produced better results. Use of a $150 \mathrm{~kg}$ nitrogen application was beneficial only when $100 \mathrm{~kg} \mathrm{~N} / \mathrm{ha}$ had been applied in the autumn and the remaining $50 \mathrm{~kg}$ put on as heading started. 2. Large single applications of nitrogen lowered the bulk weight. There were no significant differences in the 1000 kernel weights. 3. The various levels of nitrogen manuring caused no significant differences in falling number. 4. The larger the nitrogen application, the higher was the protein content of the grain. A split application of nitrogen produced higher protein contents than a large, single application. 5. Zeleny values were generally higher when all the nitrogen was put on during the same growing season. 6 . There were no differences due to nitrogen manuring levels, in ash contents or in flour yields. 7. The wet gluten of the flour followed the protein content. There were no differences in Pelshenke's value or in swelling number. 8. No significant differences were found in valorimetric values. However, the length of the extensogram, or extensibility of the dough followed the protein content. The height of the extensogram, or resistance to extension was better correlated with swelling number. 9. There were no significant differences in water absorption capacity, though the trend was positive with the larger nitrogen doses. 10. Fermentation time and the use of additives produced at least as great an effect upon the results of the baking test as did nitrogen manuring level. 11. The cultivars tested reacted dirferently to nitrogen manuring. The results of the baking test on the cultivars Linna and Elo, with weak gluten, generally varied negatively when increasingly large dressings of nitrogen were applied, whereas line a $\mathbf{7 7 8 0}$ with strong gluten reacted less sharply and, to some extent even positively to an increase in nitrogen manuring.
\end{abstract}


Typen käytön lisääntyminen viljakasveilla 1960-luvulla herätti kysymykset suurten lannoitemäärien ajoittamisesta tai jakamisesta (FAJERSSON 1961, Raininko 1966, KöylJjäRvi 1969, 1972, Pessi ym. 1971). Näihin ongelmiin liittyen järjestettiin Hankkijan kasvinjalostuslaitoksen Anttilan koetilalla typpilannoituskokeita syysvehnällä vuosina 1968/69-1969/70. Kokeissa haluttiin selvittää myöhäisen syyslevityksen ja kevätlevityksen eroja sekä suurten typpimäärien jakamisen vaikutusta sadon määrään ja sen laatuun.

\section{Koeaineisto ja sen käsittely}

Koeaineisto koostui kolmesta kokeesta, joista kaksi järjestettiin vuonna 1968/69 Linna- ja Elo-lajikkeilla sekä yksi vuonna 1969/70 a7780-syysvehnälinjalla. Elo ja Linna edustavat tunnetusti leivinkelpoisuudeltaan heikohkoa syysvehnää, kun taas linja a7780 on hyvä- ja runsassitkoinen jaloste.

Koekaava oli seuraava:

\begin{aligned} N kg/ha & Levitysaika \\ \hline 50 & syksyllä $(01.12 \\ 50 &$. keväällä $(03.05 \\ 100 &$. syksyllä $(01.12 \\ 100 &$. keväällä $(03 \cdot 05 \\ . 50+50 &$ syks. + tähk. alussa $(24.06 \\ . 50+50 &$ kev. + tähk. alussa \\ $100+50 &$ syks. + tähk. alussa \\ $100+50 &$ kev. + tähk. alussa \end{aligned}

Kokeet perustettiin talousviljelmille monitekijäkokeena. Maalaji oli hietasavea. Ruutukoko oli $7 \mathrm{~m}^{2}$, kerranteita 4 . Typpilannoitus annettiin syksyllä tai keväällä pintalannoituksena, kesällä ruiskuttaen Oulun salpietarina tai ureana siten, että kaksi kerrannetta lannoitettiin molemmilla. Tulosten esittelyssä ei typpilannoitteiden välisiä eroja ole käsitelty, koska ne olivat kauttaaltaan pieniä ja tilastollisesti vain harvoin merkitseviä.

Kasvustohavaintojen ja sadon määrän lisäksi määritettiin kustakin ruutusadosta hl-paino, 1000 jyvän paino, sakoluku, viskoluku, proteiinipitoisuus ja Zeleny-luku. Koejäsenten leivinkelpoisuus tutkittiin SOK:n myllyllä Nokialla näytteistä, joihin oli yhdistetty kaikki neljä kerrannetta. Erilaiset määritykset ja varsinainen leivontakoe suoritettiin Viljantutkimustoimikunnan ohjeiden mukaan. Leivonnassa käytettiin nostatusaikoja $30+40 \mathrm{~min}, 30+60 \mathrm{~min}$ ja $30+80$ min. Leivonta tehtiin kahdella taikinatyypillä: 1) 450 g jauhoja, $270 \mathrm{ml}$ vettä, $22.5 \mathrm{~g}$ hiivaa ja $9.0 \mathrm{~g}$ suolaa, 2) edellisten lisäksi $13.5 \mathrm{~g}$ sokeria, $13.5 \mathrm{~g}$ rasvaa ja $15 \mathrm{ppm}$ askorbiinihappoa.

Tulosten tilastolliseen käsittelyyn käytettiin varianssi- ja multiregressioanalyysejä, jotka laskettiin Keskusosuusliike Hankkijan ATK-osastolla. Tulosten merkitsevyys on ilmaistu tavanomaiseen tapaan. 
Taulukko 1. Varianssianalyysi typpilannoituksen ja sen ajoittamisen vaikutuksesta syysvehnän satoon ja sadon laatuun.

Table 1. Analysis of variance of the effects of nitrogen application and its timing on the yield and quality of winter wheat.

\begin{tabular}{|c|c|c|c|c|c|c|c|}
\hline & $\begin{array}{l}\text { Tekijä } \\
\text { Factor }\end{array}$ & $\begin{array}{c}\text { Jyväsato } \\
\text { Grain } \\
\text { yield }\end{array}$ & $\begin{array}{c}\text { Hl-paino } \\
\text { Bulk } \\
\text { weight }\end{array}$ & $\begin{array}{l}1000 \text { jp. } \\
1000 \text { k.w. }\end{array}$ & $\begin{array}{l}\text { Sakoluku } \\
\text { Falling } \\
\text { number }\end{array}$ & $\begin{array}{c}\text { Proteiini- } \\
\text { pitoisuus } \\
\text { Protein } \\
\text { content }\end{array}$ & $\begin{array}{l}\text { Zeleny- } \\
\text { luku } \\
\text { Zeleny- } \\
\text { value }\end{array}$ \\
\hline A. & $\begin{array}{l}\text { Lajike } \\
\text { Cultivar }\end{array}$ & $* * *$ & $* * *$ & $* * *$ & $* * *$ & $* * *$ & $*$ \\
\hline B. & $\begin{array}{l}\text { Typpilannoitus } \\
\text { Nitrogen application }\end{array}$ & $(*)$ & $*$ & ns & ns & $* *$ & $(*)$ \\
\hline$A B$ & & ns & ns & ns & ns & $(*)$ & ns \\
\hline
\end{tabular}

\section{Jyväsato}

Jyväsadoissa oli merkitseviä eroja eri koejäsenien välillä (Taulukko 1, B) Erot toistuivat samansuuntaisina jokaisessa kolmessa kokeessa (AB).

Käytettäessä $50 \mathrm{~kg}: n$ typpiannosta saatiin paras tulos antamalla se keväällä kasvun alkaessa (Taulukko 2). Sen sijaan $100 \mathrm{~kg}: \mathrm{n}$ annos tuotti parhaan tuloksen joulukuun alussa annettuna. Jaetut 100 tai $150 \mathrm{~kg}: \mathrm{n}$ annokset tuottivat paremman tuloksen kuin yksi iso annos keväällä. $150 \mathrm{~kg}: \mathrm{n}$ annoksista oli paras 100 syksyllä +50 tähkimisen alkaessa, mikä tapa tuotti myös koko kokeen parhaan tuloksen. Sen sijaan $150 \mathrm{~kg}$ N saman kasvukauden aikana oli selvästi epäedullinen tapa käyttää typpeä.

Typpilannoituksen ajankohtaa syysvehnällä ovat meillä selvittäneet Köylijärvi $(1969,1972)$ ja Pessi ym. (1971). Edellisen mukaan n. 100 kg:n typpiannoksella saatiin paras tulos aikaisella kevätlevityksellä. Pessın ym. (1971) mukaan taas joulukuussa annettu typpilannoitus tuotti kevätlevitystä paremman sadon. Tulosten ristiriitaisuuteen voi tästä koesarjasta yrittää löytää selvitystä siitä yhdysvaikutuksesta, mikä oli todettavissa typen määrän ja levitysajan välillä. Suhteellisen pieni typpimäärä $(50 \mathrm{~kg})$ keväällä antoi yhtä hyvän tuloksen kuin isompi määrä $(100 \mathrm{~kg})$ syksyllä, kun taas iso määrä keväällä ilmeisesti meni yli optimaalisen kerta-annoksen. Tähän viittaavat myös esim. Boguslawskin (1965) tulokset, joissa yli $40 \mathrm{~kg}$ :n typpimäärät keväällä annettuna oli edullista jakaa useampaan annokseen. Se että KöyLIJÄRVEN kokeissa vielä $100-150 \mathrm{~kg}$ typpeä oli edullisin keväällä annettuna, voi johtua vehnän erilaisesta typen saannista eri olosuhteissa.

Jaetut $100 \mathrm{~kg}: n$ typpiannokset kevätlannoituksessa antoivat tässä kokeessa jakamattomiin verrattuna sadonlisäyksiä, ei tosi merkitseviä. Syyslannoituksessa vastaava ilmiö tuli esille 100 syks. +50 tähk. koejäsenessä. RAInıngon (1966) kokeissa kevätvehnällä tähkimisvaiheessa annettu typpilisä ei nostanut satoa hänen käyttämillään pienillä typpimäärillä. Lieneekin niin, että jaettu typpiannos antaa sadonlisäystä vain silloin, kun tällä tavalla vältytään liialta typen kertakäytöltä keväällä. Suuren keväisen kerta-annoksen haitallisuus perustuu liialliseen vegetatiiviseen kasvuun, mistä on seurauksena veden ja ravinteiden tuhlaus, jopa vajaus jyvänmuodostuksen aikana, sekä lakoutuminen, mitkä tekijät estävät jyväsadon suoraviivaista lisääntymistä. 
Taulukko 2. Typpilannoituksen ja sen ajoittamisen vaikutus syysvehnän satoon.

Table 2. Effects of nitrogen application and its timing on the grain yield of winter wheat.

\begin{tabular}{|c|c|c|c|c|c|c|c|c|}
\hline & & $\begin{array}{l}\text { Koejäsen } \\
\text { Treatment }\end{array}$ & $\begin{array}{l}\text { Jyväsato } \\
\text { irain yield } \\
\mathrm{kg} / \mathrm{ha}\end{array}$ & $\begin{array}{c}1000 \mathrm{pj} . \\
1000 \text { k.w. } \\
\mathrm{g}\end{array}$ & $\begin{array}{c}\text { Hl-paino } \\
\text { Bulk weight } \\
\text { kg }\end{array}$ & $\begin{array}{l}\text { Sakoluku } \\
\text { Falling } \\
\text { number }\end{array}$ & $\begin{array}{l}\text { Prot. } \% \\
\text { Protein } \\
\text { content }\end{array}$ & $\begin{array}{c}\text { Zeleny- } \\
\text { luku } \\
\text { Zeleny } \\
\text { value }\end{array}$ \\
\hline 50 & $\mathrm{~N}$ & $\begin{array}{l}\text { syksyllä ........................ } \\
\text { autum }\end{array}$ & 4130 & 44.1 & 80.5 & 333 & 12.0 & 50 \\
\hline 50 & N & $\begin{array}{l}\text { keväällä } \ldots \ldots \ldots \ldots \ldots \ldots \ldots \ldots \ldots \\
\text { spring }\end{array}$ & 4390 & 43.7 & 80.4 & 333 & 12.3 & 51 \\
\hline 100 & N : & $\begin{array}{l}\text { syksyllä } \\
\text { autum }\end{array}$ & 4400 & 44.7 & 80.0 & 330 & 12.7 & $; 49$ \\
\hline 100 & N & $\begin{array}{l}\text { keväällä } \ldots \ldots \ldots \ldots \ldots \ldots \ldots \ldots \ldots \\
\text { spring }\end{array}$ & 4140 & 44.2 & 79.7 & 331 & 13.0 & 56 \\
\hline 50 & $\mathrm{~N}$ & $\begin{array}{l}\text { syksyllä }+50 \mathrm{~N} \text { tähk. .... } \\
\text { autumn } \\
\text { at heading }\end{array}$ & 4370 & 44.0 & 80.5 & 324 & 13.0 & 52 \\
\hline 50 & N & $\begin{array}{l}\text { keväällä }+50 \mathrm{~N} \text { tähk. ... } \\
\text { spring } \\
\text { at heading }\end{array}$ & 4380 & 44.2 & 80.7 & 330 & 13.6 & 55 \\
\hline 100 & $\mathrm{~N}$ & $\begin{array}{l}\text { syksyllà }+50 \mathrm{~N} \text { tähk. ..... } \\
\text { autumn } \\
\text { at heading }\end{array}$ & 4740 & 44.7 & 80.1 & 331 & 13.8 & 51 \\
\hline 100 & & $\begin{array}{l}\text { keväällä }+50 \mathrm{~N} \text { tähk. ... } \\
\text { spring at heading }\end{array}$ & 4210 & 44.1 & 80.0 & 330 & 14.2 & 56 \\
\hline PME & $\mathrm{E}-$ & $-L S D(5 \%) \quad \ldots \ldots \ldots \ldots \ldots \ldots$ & 340 & ns & 0.6 & ns & 0.6 & 6 \\
\hline
\end{tabular}

\section{Lakoutuminen}

Lakoa esiintyi ainoastaan yhdessä kokeessa, Elo-68. Sen kokeen lakohavainnot olivat seuraavat:

$\begin{array}{llll}\text { N } 50 \text { syks. } & & 8 \% \text { lakoa } \\ \text { N } 50 \text { kev. } & & 14 \\ \text { N } 100 \text { syks. } & & 22 \\ \text { N } 100 \text { kev. } & & 27 \\ \text { N } 50 \text { syks. + N } 50 \text { tähk. } & 15 \\ \text { N } 50 \text { kev. + N } 50 & 19 \\ \text { N } 100 \text { syks. + N } 50 & 22 \\ \text { N } 100 \text { kev. + N } 50 & 17\end{array}$

Lakoutuminen noudatti melko hyvin typpimääriä, kuten yleensä on asian laita (vrt. Mukula ja Teittinen 1973). Pessi ym. (1971) totesivat syyslevityksen aiheuttavan rukiilla vähemmän lakoa kuin kevätlevityksen, mihin myös tämän kokeen tulokset viittaavat.

\section{0 jyvän paino}

1000 jyvän painoissa (Taulukko 2) ei todettu merkitseviä eroja. FAJERsson (1961) totesi typpilannoituksen lisäämisen yleensä nostavan 1000 jyvän painoa, paitsi, jos keväällä käytettiin suurta kerta-annosta. Myöhään' annettu 
lisätyppi suurensi hänen kokeissaan jyväkokoa. Samaan viittaavat RAININGoN (1966) ja May (1970) tulokset. Pessin (1971) kokeissa samoin kuin tässä esitetyissä jyväkoko myötäili melko hyvin satotuloksia osoittaen, että sadonlisäykset perustuivat todennäköisesti pääasiassa jyväkoon suurenemiseen. BENGTSSON (1974) totesi puolestaan lisätyn typpilannoituksen lisäävän sekä tähkien lukumäärää että jyvien kokoa.

\section{Hl-paino}

Hehtolitran painossa (Taulukko 2) oli merkitseviä, tosin suhteellisen pieniä eroja. Yleensä suuri kerta-annos typpeä, annettiinpa se milloin tahansa, näytti alentavan hl-painoa. Joissakin tapauksissa oli havaittavissa suuren typpiannoksen jälkeen jälkiversontaa, mikä saattaa selittää hl-painon alentumisen. FAJERssonin (1961) ja BEngtssonin (1974) tutkimuksissa lisätty typpilannoitus nosti hl-painoa, jaettu annostus enemmän kuin iso kerta-annos, Rainingon (1966) kokeissa tulos oli vaihteleva. Pessin ym. (1971) kokeissa erot olivat vähäisiä.

\section{Sakoluku}

Tärkkelyksen kuntoa ilmaisevaan sakolukuun ei typpilannoituksella ollut vaikutusta.

FAJERSSONin (1961) mukaan typpilannoituksen lisääminen alensi vehnän diastaattista aktiviteettia, mikä merkitsi sakoluvun kohoamista. Päinvastaiset tulokset johtuvat hänen mukaansa typpilannoituksen välillisestä, lakoutumista lisäävästä vaikutuksesta, mikä puolestaan johtaa sakoluvun alenemiseen. Raininko (1966) ja Pessi ym. (1971) eivät todenneet selviä typpilannoituksesta johtuvia muutoksia sakoluvuissa. Sen sijaan MAY (1970) tutkimuksissa tuli esille, että tähkäidännänkestävillä lajikkeilla myöhäinen typpilannoitus nosti sakolukua, kun taas tähkäidäntäherkät lajikkeet reagoivat päinvastaisesti. Rengtssonin (1974) typpilannoituskokeissa sakoluku muuttui eri kokeissa eri suuntaan.

\section{Proteiinipitoisuus}

Sadon proteiinipitoisuus nousi sitä mukaa kuin typpilannoitusta lisättiin (Taulukko 2). Kevätlevityksessä proteiinipitoisuus oli korkeampi kuin syyslevityksessä. Samoin jaettu typpiannos tuotti korkeampia proteiinipitoisuuksia kuin iso kerta-annos.

Muiden tutkijoiden tulokset ovat proteiinipitoisuuksien suhteen täysin samanlaisia (FAjersson 1961, Boguslawski 1965, Raininko 1966, Braun 1970, May 1970, Lampinen 1971, Pessi ym. 1971, Bengtsson 1974, Kolderup 1974). Tässä koesarjassa proteiinipitoisuus nousi typpilannoituksen mukana niissäkin tapauksissa, missä sadonlisäys oli merkitsevä. Tämä lienee tulkittavissa osoitukseksi siitä, että typen määrä ei ollut ainoa sadon suuruutta rajoittava tekijä (vrt. Kolderup 1974). 
Taulukko 3. Varianssianalyysi typpilannoituksen ja sen ajoituksen vaikutuksesta syysvehnän leivinkelpoisuuteen.

Table 3. Analysis of variance of the effects of nitrogen application and its timing on the baking quality of winter wheat.

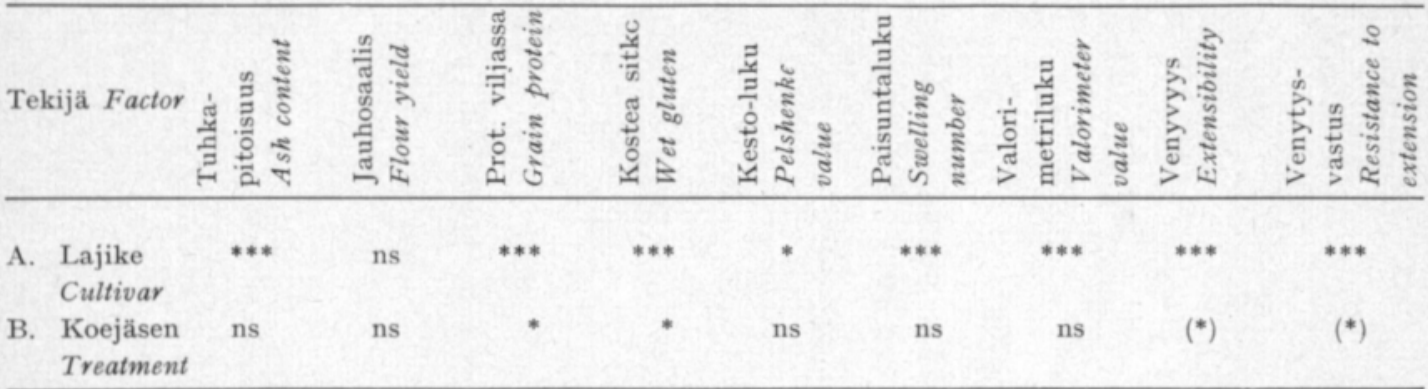

\section{Zeleny-luku}

Sadon valkuaisen määrää ja laatua ilmaiseva Zeleny-testi tehtiin kahdesta kokeesta. Erot olivat lievästi merkitseviä. Ne eivät olleet täysin johdonmukaisia eivätkä täysin seuranneet proteiinipitoisuuksia. BRAUnin (1970) tutkimuksissa aikainen lisätyppi ei juuri vaikuttanut Zeleny-lukuun, mutta myöhäinen typpilannoitus nosti sitä selvästi. BogusLAwskin (1965) ja BENGTSsovin (1974) typpilannoitustutkimuksissa Zeleny-luvut noudattivat sangen hyvin proteiinipitoisuuksien muutoksia. MAYn (1970) tutkimuksissa myöhäinen lisätyppi nosti selvästi kaikkien lajikkeiden Zeleny-lukuja, jopa nopeammin kuin mitä proteiinipitoisuus nousi. Lajikkeiden välillä oli BoGUSLAwskın (1965) tutkimuksissa se ero, että hyväsitkoisilla lajikkeilla Zeleny-luvut paranivat proteiinipitoisuuden noustessa, mutta huonositkoisilla selviä eroja ei todettu. Selostettavassa tutkimuksessa lienee lähinnä kysymys jälkimmäisestä tapauksesta, missä heikkositkoisten Linnan ja Elon Zeleny-luvut muuttuivat sangen vähän proteiinipitoisuuden noustessa.

\section{Sadon leivinkelpoisuus}

Varianssianalyysien tulokset leivintutkimuksista on esitetty Taulukossa 3 .

Yhteenveto leivintutkimusten tuloksista on esitetty Taulukossa 4.

Jyvien tuhkapitoisuudessa ei ollut typpilannoituksesta johtuvia merkitseviä eroja. FAJERSSON (1961) päätyi samaan tulokseen. MAY (1970) ei todennut syysvehnällä selviä muutoksia, kevätvehnällä tulos vaihteli eri tapauksissa.

Jauhatusteknillisiä ominaisuuksia osoittava jauhosaalis ei muuttunut merkitsevästi typpilannoituksesta johtuen, eikä mitään selvää suuntaakaan ollut havaittavissa. Samaan tulokseen tuli Bengtsson (1974). Fajerssonin (1961) ja MAYn (1970) tutkimuksissa typpilannoitus paransi vehnän jauhatusominaisuuksia lisäämällä jyvän kovuutta. Tämä johti jauhon parempaan rakeisuuteen sekä hienon jauhon ja leseen osuuden pienenemiseen. BRAUNin (1970) mukaan aikainen typpilannoitus ei juuri vaikuttanut taikinan fysikaalisiin ominaisuuksiin, mutta myöhäinen typpilannoitus paransi niitä. 


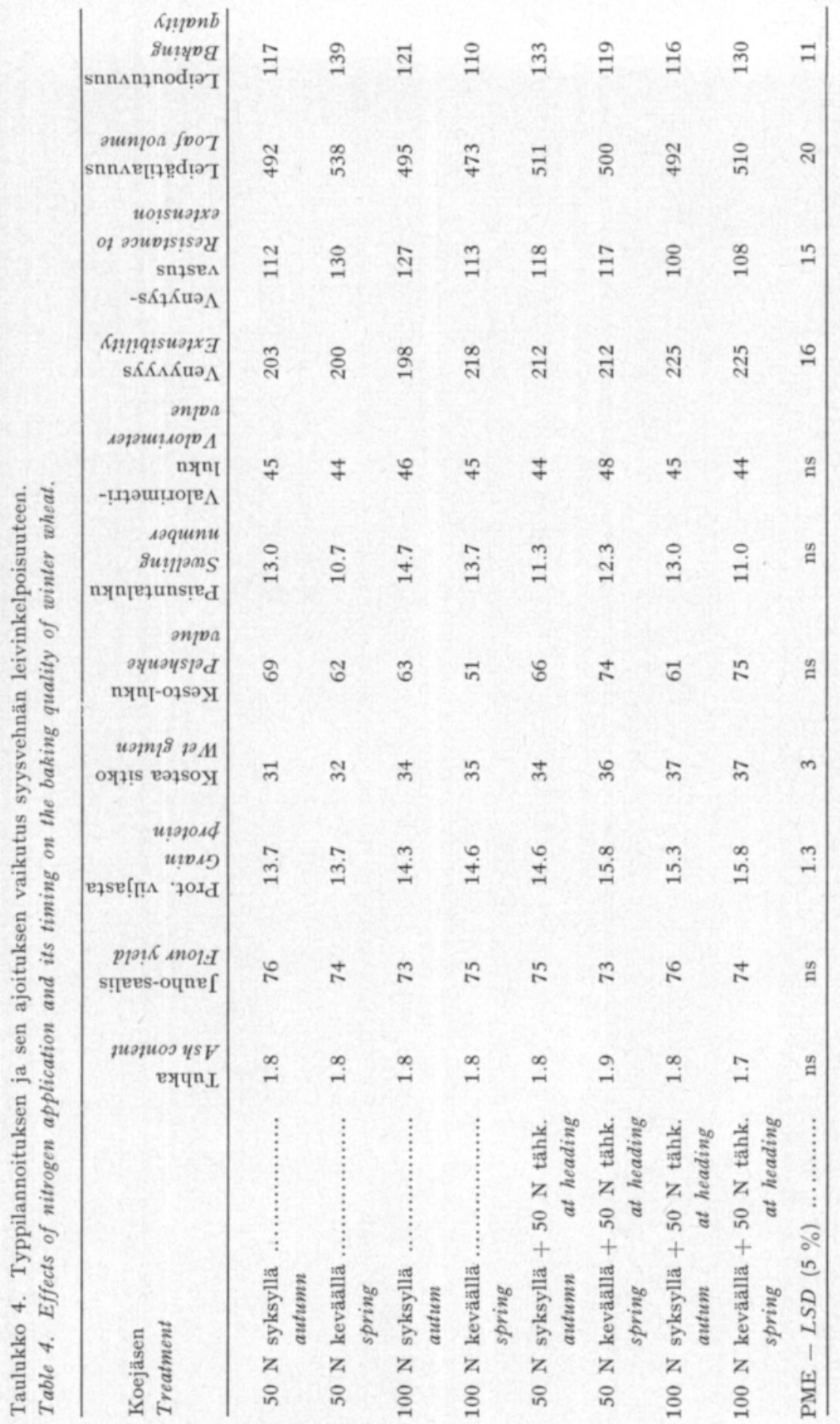


Jyvien ja jauhojen proteiinin määrää kuvaavissa luvuissa, proteiinipitoisuuksissa ja kostean sitkon määrissä, oli merkitseviä eroja. Proteiinipitoisuuksia on jo käsitelty sivulla 274. Kostean sitkon suhteen tulokset olivat yhtäpitäviä muiden tutkimusten kanssa (FAJERSSON 1961, KüRTEN 1964, BogUSLAWSKI 1965, RAININKo 1966). Ne seurasivat proteiinipitoisuuksien muutoksia.

Sitkon laatua kuvaavissa kestoluvuissa ja paisuntaluvuissa ei ollut typpilannoituksesta johtuvia merkitseviä eroja. Farinogrammista lasketuissa valorimetriluvuissa ei myöskään ollut merkitseviä eroja. Sen sijaan ekstensogrammin pituutta osoittavissa venyvyysluvuissa oli merkitseviä eroja, mitkä noudattivat melko hyvin proteiinin määrän tunnuslukuja. Saman totesi MAY (1970). Ekstensogrammin korkeutta kuvaavissa venytysvastusluvuissa oli myös merkitseviä eroja. Ne poikkesivat paremmuusjärjestyksessä selvästi venyvyysluvuista ja noudattivat enemmän muita sitkon laatua kuvaavia tunnuslukuja, kestolukua ja paisuntalukua.

FAJERsson (1961) ja Boguslawski (1965) totesivat, että typpilannoituksen lisääminen ja suurten typpiannosten jakaminen paransivat sitkon laatua hyväsitkoisilla lajikkeilla, mutta ei heikkolaatuisilla. RaIningon (1966) tutkimuksissa kevätvehnillä ei paisuntaluvuissa ollut selviä eroja, kuten ei tässäkään tutkimuksessa.

\section{Leipätilavuus}

Leivontakokeissa saaduissa leipätilavuuksissa oli useita merkitseviä eroja (Taulukot 4 ja 5). Typpilannoitus vaikutti keskimääräiseen leipätilavuuteen siten, että paras tulos saatiin koejäsenestä N 50 kev. Sen sijaan runsas typpi-

Taulukko 5. Varianssianalyysi syysvehnän leivontatulokseen vaikuttavista tekijöistă. Table 5. Analysis of variance of factors affecting results of baking test.

Leipätilavuus Leivontaluku
Loaf volume Baking quality
A. Lajike - Cultivar
B. Koejäsen - Treatment...............
C. Nostatusaika - Fermentation time
D. Lisäaineet - Additives
AB
$\mathrm{AC}$

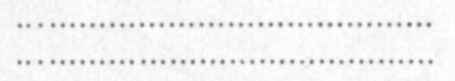
AD
$\mathrm{BC}$
BD

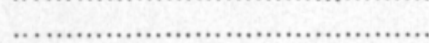
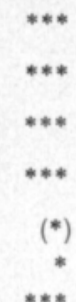

* ns
CI
ns
ns
ns
ns
(*)
$\mathrm{ABC}$
***
***
$\mathrm{ABD}$
ns
ns
$\mathrm{ACD}$
ns
BCD
***
ns
ns
***
ns 
lannoitus keväällä (N $100 \mathrm{kev}$ ) antoi huonon leipätilavuuden. Jaettujen annosten aiheuttamat muutokset olivat pieniä ja epäjohdonmukaisia. BRAUN (1970) ja MAY (1970) puolestaan totesivat myöhäisen lisätypen lisäävän leipätilavuutta sekä syys- että kevätvehnillä. Samoin BEngtsson (1974) totesi typpilannoituksen lisäämisen parantavan leipätilavuutta. Tämä ristiriita voi johtua siitä, että selostettavassa tutkimuksessa sadon proteiinipitoisuudet olivat kauttaltaan niin korkeita, ettei lisätyppi enää pystynyt parantamaan leipätilavuutta.

Nostatusaika ja lisäaineet vaikuttivat myös merkitsevästi leipätilavuuteen (Taulukot 5 ja 6). Myös niiden yhdysvaikutus (CD) oli merkitsevä. Sekä nostatusajan jatkaminen että lisäaineiden käyttö paransivat selvästi leipätilavuutta. Yhdysvaikutus osoitti, että ilman lisäaineita vasta pisin nostatusaika vaikutti leipätilavuuteen, kun taas lisäaineita käytettäessä jo keskimmäinen nostatusaika oli selvästi lyhyttä aikaa parempi. Verrattaessa näitä eroja typpilannoituksella saatuihin huomataan, että leivontatekniikan aiheuttamat erot olivat selvästi suuremmat kuin typpilannoituksen aiheuttamat erot. Nämä erot olivat lisäksi typpilannoituksesta riippumattomia, sillä yhdysvaikutukset koejäsen $\mathrm{x}$ nostatusaika (BC) ja koejäsen $\mathrm{x}$ lisäaineet (BD) eivät olleet merkitseviä.

Lajikkeet reagoivat eri tavalla sekä typpilannoitukseen että leivontatekniikkaan (AB, AC, AD). Heikkolaatuisemmat Linna ja Elo reagoivat herkemmin kuin vahvasitkoinen a7780 ja usein negatiivisesti. Viimeksimainitulla typpilannoituksen lisääminen sen sijaan jopa paransi leipätilavuutta.

Taulukko 6. Nostatusajan ja lisäaineiden vaikutus syysvehnän leivinkelpoisuuteen.

Table 6. The effects of fermentation time and additives on the baking quality of winter wheat.

\begin{tabular}{|c|c|c|c|c|c|c|}
\hline \multirow[b]{2}{*}{$\begin{array}{l}\text { Nostatusaika } \\
\text { Fermentation } \\
\text { time }\end{array}$} & \multicolumn{2}{|c|}{$\begin{array}{c}\text { Ilman lisäaineita } \\
\text { No additives }\end{array}$} & \multicolumn{2}{|c|}{$\begin{array}{c}\text { Lisäaineiden kanssa } \\
\text { With additives }\end{array}$} & \multirow{2}{*}{ 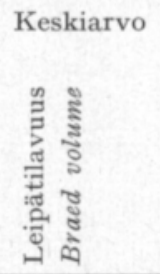 } & \multirow{2}{*}{ - Mean } \\
\hline & 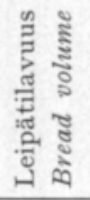 & 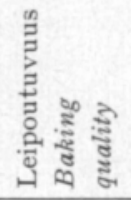 & 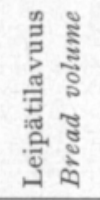 & 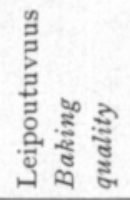 & & \\
\hline $30+40$ & 440 & 107 & 512 & 135 & 476 & 121 \\
\hline $30+60$ & 436 & 100 & 563 & 140 & 499 & 120 \\
\hline $30+80$ & 509 & 123 & 554 & 135 & 531 & 129 \\
\hline $\begin{array}{l}\text { Keskiarvo } \\
\text { Mean }\end{array}$ & 462 & 110 & 543 & 137 & - & - \\
\hline
\end{tabular}

PME - LSD

$(5 \%)$

Nostatusaika

Fermentation

time

Lisäaineet

Additives

$\mathrm{N} \times \mathrm{L}$ 
Nostatusaikaan Linna reagoi heikosti $(400,420,428)$, Elo ja a7780 selvemmin (Elo 478, 490, 541; a7780, 550, 591, 624). Lisäaineiden käyttöön kaikki lajikkeet reagoivat positiivisesti (Linna 388, 443; Elo 461, 545; ja a7780 537, $640)$.

Myös toisen asteen yhdysvaikutus ACD oli merkitsevä osoittaen, että jokaisella lajikkeella oli oma optimaalinen leivontatekniikkansa. Leivontatekniikan merkitystä eri lajikkeiden laadun arvostelemisessa korostavat $\mathrm{mm}$. Svensson ja FAJERsSon (1971).

\section{Leipoutuvuus}

Leipoutuvuusluvuissa, jotka ilmaisevat leivän tilavuutta ja rakennetta, oli myös typpilannoituksen aiheuttamia eroja (Taulukot 5 ja 6 ). Parhaat ja heikoimmat leipoutuvuusluvut olivat samoissa koejäsenissä kuin vastaavat leipätilavuudetkin, joskin pientä vaihtelua oli.

Leivontatekniikka vaikutti ilman lisäaineita leivottaessa leivontalukuihin saman suuntaisesti kuin leipätilavuuksiin (Taulukko 6). Lisäaineita käytettäessä ei nostatusaikojen välillä ollut enää merkitseviä eroja.

Lajikkeiden leipoutuvuuslukuihin typpilannoitus vaikutti jossain määrin eri tavalla $(\mathrm{AB})$. Linna ja Elo reagoivat herkemmin ja yleensä negatiivisesti typpilannoituksen lisäämiseen, kun taas linjan a7780 leipoutuvuusluvut jopa hiukan paranivat typpilannoitusta lisättäessä.

\section{Laatumääritysten merkitsevyys}

Leivintutkimuksen tuloksista haluttiin selvittää, mitkä osamääritykset parhaiten selittäisivät leipätilavuutta ja leipoutuvuutta. Tätä varten laskettiin lineaarinen multiregressioanalyysi, jossa selittäjinä olivat jauhosaalis, tuhkapitoisuus, sakoluku, proteiinipitoisuus, kestoluku, sitkon määrä, valorimetriluku, paisuntaluku, venyvyys, venytysvastus ja vedensitomiskyky. Lajikkeiden väliset erot poistettiin 01-muuttujilla. Multiregressioanalyysin tulokset on esitetty Taulukossa 7.

Taulukko 7. Multiregressioanalyysi leipätilavuuteen vaikuttavista tekijöistä

Table 7. Multiple regression analysis of the factors influencing loaf volume and baking quality.

\begin{tabular}{|c|c|c|c|c|}
\hline \multirow[t]{2}{*}{$\begin{array}{l}\text { Selittäjä } \\
\text { Variable }\end{array}$} & \multicolumn{2}{|c|}{$\begin{array}{l}\text { Leipätilavuus } \\
\text { Loaf volume }\end{array}$} & \multicolumn{2}{|c|}{$\begin{array}{l}\text { Leipoutuvuus } \\
\text { Baking quality }\end{array}$} \\
\hline & b & $\mathrm{r}$ & b & $\mathbf{r}$ \\
\hline Venytysvastus - Resistance to extension & 1.44 & 0.83 & 0.58 & 0.80 \\
\hline Kestoluku - Pelschenke value ............ & 0.52 & 0.39 & 0.24 & 0.39 \\
\hline Lajikkeet - Cultivars .................... & ns & ns & 11.86 & 0.46 \\
\hline 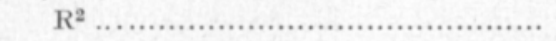 & $90 \%$ & - & $88 \%$ & - \\
\hline k & 301 & - & 35 & - \\
\hline
\end{tabular}


Taulukko 8. Laatuanalyysien korreloituminen (r) leivontatutkimuksen tuloksiin. Table 8. Correlation of quality tests with the results of baking tasts.

\begin{tabular}{|c|c|c|}
\hline & $\begin{array}{l}\text { Leipätilavuus } \\
\text { Loaf volume }\end{array}$ & $\begin{array}{l}\text { Leipoutuvuus } \\
\text { Baking quality }\end{array}$ \\
\hline Prot.- $\%$ - Protein content ........................... & $+0.55^{* *}$ & $+0.43^{*}$ \\
\hline 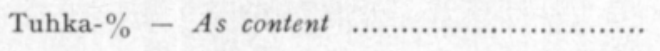 & -0.33 & -0.40 \\
\hline Sakoluku - Falling number ........................... & $-0.77 * * *$ & $-0.66 * * *$ \\
\hline Vedensitomiskyky - Water absorption capacity & -0.35 & -0.38 \\
\hline Jauhosaalis - Flour yield ......... & +0.19 & +0.16 \\
\hline Kestoluku - Pelshenke value ........................ & $+0.81 * * *$ & $+0.82 * * *$ \\
\hline 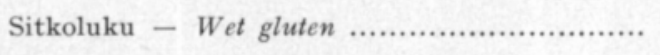 & +0.12 & +0.01 \\
\hline Paisuntaluku - Swelling number .................... & $+0.85^{* * *}$ & $+0.80^{* * *}$ \\
\hline Valorimetriluku - Valorimeter value ............... & $+0.93 * * *$ & $+0.87 * * *$ \\
\hline Venyvyys - Extensibility ................... & $+0.49^{*}$ & $+0.43^{*}$ \\
\hline Venytysvastus - Resistance to extension ........ & $+0.94 * * *$ & $+0.90 * * *$ \\
\hline Lajike $1-$ Cultivar.......... & $+0.41^{*}$ & $+0.73 * * *$ \\
\hline 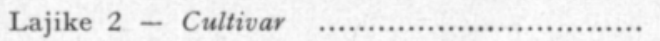 & $+0.73^{* * *}$ & $+0.98 * * *$ \\
\hline
\end{tabular}

Leipätilavuutta selittäviksi merkitseviksi tekijöiksi tulivat malliin mukaan taikinan kimmoisuutta ja sitkon kestävyyttä kuvaavat venytysvastusluku ja kestoluku. Leipoutuvuuslukujen selittäjiksi tulivat samat tekijät sekä lisäksi lajiketekijä, mikä on osoituksena lajikkeen perinnöllisten ominaisuuksien merkityksestä leivinkelpoisuuden perustekijänä. Näiden malliin mukaan tulleiden selittäjien lisäksi korreloivat eräät muutkin määritysarvot merkitsevästi leivontatutkimuksen tulosten kanssa (Taulukko 8).

Venytysvastuksen, kestoluvun ja lajiketekijäin lisäksi oli korkea korrelaatiokerroin valorimetriluvulla, paisuntaluvulla ja sakoluvulla. Viimeksimainittu korreloitui negatiivisesti leivontatulokseen, mikä johtunee sakolukujen korkeudesta tässä aineistossa. Proteiinipitoisuuden selittävyys oli suhteellisen huono.

Proteiinipitoisuuden huonon korreloitumisen leipätilavuuteen syysvehnillä totesi myös FAJERSSON (1951). Hänen mukaansa ylimääräisellä typpiannoksella aikaansaatu lisäsitko on laadultaan niin huonoa, ettei se ole leivonnassa täysipainoista. BENGTSsonin (1974) tutkimuksissa puolestaan proteiinipitoisuuden ja leipätilavuuden välinen korrelaatio oli selvä.

Hollantilaisissa tutkimuksissa on todettu kestoluvun käyttökelpoisuus leivintutkimuksissa (Meppelink ym. 1959). Pollhamer (1962) totesi myöhäisen typpilannoituksen lisäävän sitkon venyvyyttä, minkä hän totesi vaikuttavan haitallisesti leivontatulokseen. Syyksi hän totesi muuttuneen valkuaisainekoostumuksen. BRAUnin (1970) laskemassa multiregressioanalyysissä tulivat merkitseviksi selittäjiksi jauhon proteiinipitoisuus, taikinan vedenpidätyskyky ja taikinan venyvyys. 
Leivontatutkimuksissa tehtyjen osamääritysten korreloitumisesta leipätilavuuteen on siis eri tapauksissa saatu jossain määrin toisistaan poikkeavia tuloksia. Nämä johtuvat ainakin osittain lajikemateriaalin erilaisuudesta (MAY 1970, BEngtsson 1974). Myös koeolosuhteilla, varsinkin käytetyillä lannoituksilla, sekä leivontatekniikalla on oma merkityksensä tulosten vaihte levuuteen.

\section{Yhteenveto}

Syysvehnän typpilannoituksen määrää ja levityksen ajankohtaa selvittävissä tutkimuksissa vuosina 1968-70 Hankkijan kasvinjalostuslaitoksen Anttilan koetilalla päädyttiin seuraaviin tuloksiin:

- Edullisin levitysaika oli riippuvainen typpiannoksen suuruudesta. Käytetty pieni määrä, $50 \mathrm{~kg} / \mathrm{ha} \mathrm{N}$, oli edullisinta antaa keväällä, kun taas $100 \mathrm{~kg} / \mathrm{ha} \mathrm{N}$ antoi parhaan tuloksen myöhään syksyllä käytettynä. Keväällä annettu $100 \mathrm{~kg}: \mathrm{n}$ typpiannos osoittautui kerta-annoksena haitallisen suureksi. Sen jakaminen kahteen levityskertaan oli edullista. 150 kg:n typpiannoksen käyttö oli edullista vain, kun peruslannoituksena oli käytetty $100 \mathrm{~kg} / \mathrm{ha} \mathrm{N}$ syksyllä ja loppu $50 \mathrm{~kg}$ tähkimisen alussa.

- Suuret kerta-annokset typpeä alensivat hl-painoa. 1000 jp:ssa ei ollut merkitseviä eroja.

- Sakoluvuissa ei ollut typpilannoituksesta johtuvia eroja.

- Jyvien proteiinipitoisuus oli sitä korkeampi mitä suurempaa typpiannosta käytettiin. Jaettu typpiannos tuotti korkeampia proteiinipitoisuuksia kuin suuri kerta- annos.

- Zeleny-luvut olivat yleensä korkeampia, jos kaikki typpi annettiin saman kasvukauden aikana.

- Jyvien tuhkapitoisuudessa ja jauhosaaliissa ei ollut typpilannoituksesta johtuvia eroja.

- Jauhon kostean sitkon määrä noudatti proteiinipitoisuutta. Kestoluvussa ja paisuntaluvussa ei ollut eroja.

- Valorimetriluvuissa ei ollut merkitseviä eroja. Sen sijaan ekstensogrammin pituus eli taikinan venyvyys noudatti proteiinipitoisuutta. Ekstensogrammin korkeus eli venytysvastus korreloi paremmin paisuntalukuihin.

- Taikinan vedensitomiskyvyssä ei ollut merkitseviä eroja, joskin suunta oli paraneva typpimäärän lisääntyessä.

- Leipätilavuutta selittivät parhaiten venytysvastusluku ja kestoluku, leipoutuvuutta edellisten lisäksi lajike.

- Nostatusaika ja lisäaineiden käyttö leivonnassa vaikuttivat vähintäin yhtä paljon leivontatulokseen kuin typpilannoitus.

- Käytetyt lajikkeet reagoivat eri tavalla typpilannoitukseen. Heikkositkoisten Linnan ja Elon leivontatulos muuttui suuria typpiannoksia käytettäessä yleensä negatiiviseen suuntaan, kun taas vahvasitkoinen linja a7780 reagoi lievemmin ja osittain jopa positiivisesti typpilannoituksen lisäämiseen. 


\section{KIR JALLISUUTTA}

Bengtsson, A. 1974. Kombinerade sort- och kvävegödslingeförsök med höstvete. Lantbr.högsk. Medd. A 223: 1-33.

Boguslawski, E. 1965. Düngung, Ertrag und Qualität bei Weizen. Getreide und Mehl 15: 19-20.

Braun, H. 1970. Die Erzeugung proteinreicher Aufmischweizen mit Hilfe ausgewählter Sorten und spezifische1 Ernährungsbedingungen. Z. Acker Pfl.bau 132: 135-150.

FAJERSSON, F. 1951. Råproteinhalt och brödvolym. Agri Hort. Gen. 9: 1-9.

-1 1961. Nitrogen fertilization and wheat quaiity. Agr. Hort. Gen. 19: 1-176.

Kolderup, F. 1974. Effect of nitrate, sulphate and time of fertilizer appiication on protein production in wheat. Meld. Norg. Landbr.høgskole 53, 10:1-26.

Kürtex, P. W. 1964. Düngung wom Qualitätsweizen. Eoden und Pflanze, 1964: $32-47$.

KöYL.JÄrvi, J. 1969. Näinkin voi kåydä. Koetoim. ja Käyt. 26: 37.

- - 1972. Syysviljojen typpi syys-, talvi- vai kevätlevityksenä. Koetoim. ja Käyt. 29: 38.

LAmpinen, R. 1971. Typpilannoitusko syysvehnän laadun parantaja? Käytännōn Maamies 1971, 2: $16-17$.

MAY, H. 1970. Ủber müllerei- und bäckereitechnologische sowie einige ernährungsfysiologische Qualitätseigenschaften bei Weizen unter dem Einfluss von Sorte und StickstoffSpätdüngung. Giessen 1970. Diss. 272 p.

Meppelink, E. K., Belderok, B. \& de Rutter, D. 1959. Ergebnisse einer Vergleichsuntersuchung von Methoden zur Bestimmung des Backwertes von kleinen Weizenmustern. Getreide und Mehl 9:125-130.

Mukula, J. \& Tertrinen, P. 1973. Typpilannoituksen, kasvutiheyden ja rikkakasvien torjunnan vaikutus kevätvehnän lakoutumiseen. Kehittyvä Maatalous 14: 10-14.

Pessi, Y., Ylänen, M., Leskelä, A. \& Syvälahtr, J. 1971. Autumn and winter application of nitrogen fertilizers on clay soils. J. Scient. Agric. Soc. Finl. 43: 76-85.

Pollhamer, S. 1962. Some problems of quality and quality test in wheat. Symp. Gen. Wheat Breeding 1962: 329-352.

Ranınko, K. 1966. Myöhäisen typpilannoituksen vaikutus kevätvehnän satoon ja leivinominaisuuksiin. J. Scient. Agric. Soc. Finl. 38: 140-149.

Svensson, G. \& Fajersson, F. 1971. Einfluss der Weizersorte auf die Backergebnisse bei variirender Backmethodik. Die Mühle 108: 757-758, 751. 